\section{STRATEGIST LIBRARIAN ON SOCIAL MEDIA: \\ Conceptual approach and possibilities of digital marketing in public libraries}

\author{
Barbara Coellho Neves*
}

Keywords: Strategist librarian - concept elaboration. Digital marketing. Digital social media. Communication and Information Processing. Sociodigital inclusion.
* Doutora em Educação pela Universidade Federal da Bahia, Brasil. Professora dos Programas de Pós-Graduação em Educação e em Ciências da Informação da Universidade Federal da Bahia, Brasil. Pesquisadora Líder do Laboratório de Pesquisas em Tecnologias Informacionais e Inclusão Sociodigital - LTIDigital.

E-mail: babi.coelho7@gmail.com.

\section{INTRODUCTION: conceptualizing the research and the construction of the objective}

r The experience gained in graduation, research, extension and teaching, which has been developing itself in recent years, has raised questions such as: How can digital marketing stimulate new discussions in the context of sociodigital inclusion in public libraries? What difficulties do public libraries present when using digital social media? If it is possible to create marketing strategies for the digital presence of companies, can it be recreated for libraries? If it is possible, how to conceptualize the professional of these units of information, which is able to develop strategies for digital social media?

Such questions, facing the issue, contributed to the formulation of the research problem: how have public libraries been developing strategies for social inclusion, through the introduction of social media, considering aspects of digital marketing? The general objective is to investigate aspects of the 
strategist librarian on digital social media, as a contemporary element of sociodigial inclusion.

The integration of TICs (Technology of Information and Communication) into the practices of the librarian has been a complex theme that articulates social, technological, psychological and didactic aspects. The individual is imbued in an environment where the media forms of communication stand out in a cyber culture with a predominance of various types of stimuli: synesthetic, visual and auditory with texts loaded with colors, sounds, words and images.

The first justification for discussing this subject is the fact that the digital marketing theme is still little approached in the academic scope of Information Science and Education, being commonly approached by researchers in the area of Administration. The contribution of the elaboration of the concept strategist librarian on social media ${ }^{\circledR}$ is important for the understanding of this movement in its spatial, social and political dimension. Therefore, the promising aspect of this article is to ensure and enable a discussion on this subject along with the theme of sociodigital inclusion in public libraries.

Given the current scenario, it is observed that TICs has evolved in the librarian context. The professionals of this area have sought, within them training circumstances, interests and opportunities, to monitor this progress. However, sometimes there are some difficulties in using technological instruments that help in the interaction with the integral users. On the one hand, mainly from the academic point of view, there is a concern for the libraries to engage in digital social media that aims potential innovations and elements of interaction with the users in an interesting way. However, the academic literature needs guidelines pointing to recent aspects of digital marketing in public libraries, as well as success stories and conscious forms of librarians developing strategies directed to digital marketing in these information units.

In recent years, however, there has been a greater concern in this regard as many public libraries are modernizing themselves and using digital social media. In contrast with it, there are many librarians, teachers and managers, in the context of Information Science, who still have some difficulties in using TICs and new marketing potentials for information units.
Another scientific relevance is the opportunity to make a bibliographical review of the various concepts attributed to the expression "digital social media" and discuss them with the intention of proposing an acceptation titled "strategist librarian on social media ${ }^{\circledR}$ ". It is expected that this task will be able to build a new meaning, which will contribute to the advancement of researches in the digital marketing segment as a new moment for the discussions on sociodigital inclusion in the public libraries context. Thus, this study is justified for the production of knowledge, and it is expected that this work contributes socially, providing subsidy for other researches.

\section{MATERIAL AND METHOD}

As every systematic research procedure, this study will also involve the collection of data from a variety of sources, based on the methods and techniques applied. This systematization of the procedures contributes to the exploration of the research, which has as its theme the strategist librarian on social media in Brazil and in two European countries.

Talking about the methodological design, it is a research with qualitative and quantitative approach, with an exploratory and descriptive method of comparative level, adopting as methodologies, according to the procedures, the study of multiple cases with application of evaluation method of social networks and bibliographic.

The proposal of this research has been developed under a quantitative-qualitative approach. According to Demo (2013), researches with this type of approach wants to live up to the complexity of reality, bowing before it, not the other way round, being adequate to observe phenomena that appreciate the quality of the analysis in the social context.

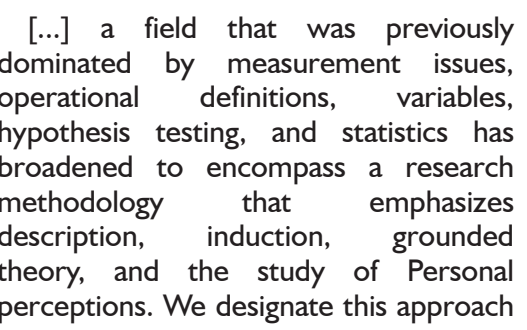


by Qualitative Investigation. (BOGAN, BICKLEN, 1994, p.II)

This research has an exploratory scope, since it intends to be guaranteed in Brazil and in Europe for making possible other researches that deepen the concept of strategist librarian on digital social media, using as object digital marketing.

In this context, the exploratory research will serve to provide familiarity with relatively unknown phenomena, to obtain information on the possibility of conducting a more complete research related to a particular context and, to research new problems. (HERNANDEZ SAMPIERI, FERNÁNDEZ COLLADO, BAPTISTA LUCIO, 2013, BEUREN, 2004). Thus, another bias, which indicates the denomination of this study as exploratory, concerns the opportunity to elaborate the concept 'strategist librarian on social media'. This is an unprecedented term in Brazilian and international literature of the Information Science.

Considering its objectives, this study also has descriptive characteristics. For the data collection, the quantitative and descriptive research uses personal interviews, questionnaires application or sampling procedures, as Oliveira (2001) affirms.

Systematic and intentional observation is also used to perform the sample selection and application of data collection instruments. With regard to these instruments of data collection, application form of observation was used to collect data from Facebook. As already pointed out earlier, this article presents the concepts and methodology of a research in progress, thus, a summary of this job is necessary for this article. It is worth mentioning that at the end of this research, a specific report will be generated with recommendations for participating librarians and their respective libraries of acting.

The steps of the procedure used in this article are: 1) the diagnosis of the essential aspects for digital marketing in public libraries and 2) the proposition-concept that addresses the potential of strategist librarians on digital social media. According to Hernández Sampieri, Fernández Collado and Baptista Lucio (2013), "[...] methods of mixed research are the systematic integration of quantitative and qualitative methods into a single study whose purpose is to obtain a more completed picture of the phenomenon". Therefore, the data collected in the first stage of this procedure will be presented below.

\section{FIRST RESULTS: likes, members and followers of the selected libraries}

The macro universe numbers 6,079 Brazilian public libraries at municipal, district, state and federal levels, in the 26 Brazilian states and in the Federal District (Brasilia).

However, the selected universe comprises the information units, specifically the public libraries, with the highest number of likes, members or followers, respectively, in their pages, groups or profiles implemented on the digital social media Facebook, in the period between 2000 and 2017, from Brazilian states and from two European countries. The two European countries were chosen based on criteria of intentionality.

The exploratory research, accomplished for sample selection, pointed to a significant volume of public libraries on Facebook. Thus, it was necessary to assign selection criteria for the information units.

In the case of Brazil, 108 public libraries were mapped in the five regions of the country. The Southeast region concentrates almost half of the public libraries on Facebook, with $46 \%$. From 108 libraries found, Southeast (51) joins South region, with $28 \%(30)$, indicating trend of concentration. The Northeast region, with 16\% (17), comes next, and the Central West (5\%) and the North $(5 \%)$ present, in each of these regions, five (5) public libraries with some digital presence on Facebook.

In this way, it was necessary to assign sample selection criteria to libraries distributed in the five Brazilian regions, based on the following criteria:

A) Libraries that actively use Facebook;

B) State and national public libraries;

C) Libraries with a number equal to 4,000

followers or greater than that.

With the observation of these criteria, the composition of the sample was reached. 
Box 1: Public libraries integrating the research sample (Brazil)

\begin{tabular}{|c|c|c|c|}
\hline REGION & LIBRARY & $\begin{array}{c}\text { LIKES } \\
\text { MEMBERS } \\
\text { PROFILES }\end{array}$ & ADRESSES \\
\hline $\begin{array}{l}\text { CENTRAL } \\
\text { WEST }\end{array}$ & $\begin{array}{l}\text { Biblioteca Nacional de } \\
\text { Brasília }\end{array}$ & 6.979 & $\begin{array}{l}\text { https://www.facebook.com/ } \\
\text { bibliotecanacional.debrasilia/likes }\end{array}$ \\
\hline NORTH & $\begin{array}{l}\text { Biblioteca Pública do Estado } \\
\text { do Acre }\end{array}$ & 4.407 & $\begin{array}{l}\text { https://www.facebook.com/bpeac/ } \\
\text { likes }\end{array}$ \\
\hline NORTHEST $^{1}$ & --- & -- & \\
\hline \multirow[t]{3}{*}{ SOUTHEST } & $\begin{array}{l}\text { Biblioteca Pública Estadual } \\
\text { Luiz de Bessa }\end{array}$ & 7.694 & $\begin{array}{l}\text { https: / / www.facebook.com / } \\
\text { bibliotecaluizdebessa/?fref=ts }\end{array}$ \\
\hline & $\begin{array}{l}\text { Biblioteca Mário de } \\
\text { Andrade }\end{array}$ & 34.040 & $\begin{array}{l}\text { https: / / ww w.facebook.com / } \\
\text { BibliotecaMariodeAndrade/?fref }=t s\end{array}$ \\
\hline & $\begin{array}{l}\text { Fundação Biblioteca } \\
\text { Nacional }\end{array}$ & 235.858 & $\begin{array}{l}\text { https: / / www.facebook.com/ } \\
\text { bibliotecanacional.br/?fref=ts }\end{array}$ \\
\hline \multirow[t]{2}{*}{ SOUTH } & $\begin{array}{l}\text { Biblioteca Pública do Estado } \\
\text { do Rio Grande do Sul }\end{array}$ & 9.166 & $\begin{array}{l}\text { https: / / www.facebook.com / } \\
\text { bibliotecapublicadoestadors/likes }\end{array}$ \\
\hline & $\begin{array}{l}\text { Biblioteca Pública Do } \\
\text { Paraná }\end{array}$ & 15.828 & $\begin{array}{l}\text { https: / / www.facebook.com/ } \\
\text { bibliotecapr/likes }\end{array}$ \\
\hline
\end{tabular}

Source: data of this research (2016)

In this way, the sample of the Brazilian public libraries, which compose the sample, comprise 7 (seven).

In order to select the public libraries from the two European countries, it was tried to follow the same criteria assigned to the sample of the Brazilian units. In Italy, the sample consists from three libraries:

- $\quad$ Nazionale Centrale di Roma library, 4.999;

- Nazionale Centrale di Firenze library, 6.344;

- Nazionale Marciana di Venezia library, with 11.042 likes on the page on Facebook.
Considering the macro universe criteria, France has 18 state and federal public libraries with some digital presence on Facebook. In this way, the following units of information, with more than 4,000 likes on their pages on Facebook, were selected for sample. ${ }^{1}$

The Northeast region did not present public libraries with a number of followers equal to 4,000 or greater than that on Facebook, considering the selection criteria of the sample in this project. However, this situation will be discussed in the developm ent of the research. 
Box 2: Public libraries integrating the research sample (France)

\begin{tabular}{|c|c|c|}
\hline LIBRARIES & LIKES & PAGES \\
\hline $\begin{array}{l}\text { Bibliotheque départementale } \\
\text { du Tarn }\end{array}$ & 4.718 & http://www.facebook.com/bibliotheque.dutarn \\
\hline Bibliothèque du Finistère & 5.091 & https://www.facebook.com/bibliothequedufinistere/ \\
\hline Bibliothèque de Bessières & 5.123 & https://www.facebook.com/bessieres31 \\
\hline Bibliothèque de Toulouse & 7.329 & $\begin{array}{l}\text { https://www.facebook.com/pages/ } \\
\text { Biblioth\%C3\%A8que-de-Toulouse/28421611469 }\end{array}$ \\
\hline Bibliothèque de Valenciennes & 7.379 & $\begin{array}{l}\text { https:/ / www.facebook.com/ } \\
\text { bibliothequevalenciennes }\end{array}$ \\
\hline $\begin{array}{l}\text { Bibliothèque Francophone } \\
\text { Multimédia - Limoges }\end{array}$ & 5.817 & https://www.facebook.com/labfmlimoges \\
\hline $\begin{array}{l}\text { Bibliothèque Intercommunale } \\
\text { Gartempe St-Pardoux }\end{array}$ & 4.486 & $\begin{array}{l}\text { https:/ / www.facebook.com/Biblioth\%C3\%A8que- } \\
\text { Intercommunale-Gartempe-St- } \\
\text { Pardoux-855794371143892/ }\end{array}$ \\
\hline $\begin{array}{l}\text { Bibliothèques Médiathèques } \\
\text { de Metz }\end{array}$ & 7.323 & https://www.facebook.com/MissMedia \\
\hline Bibliothèques Seinesaintdenis & 4.571 & $\begin{array}{l}\text { https://www.facebook.com/bibliotheques. } \\
\text { seinesaintdenis }\end{array}$ \\
\hline $\begin{array}{l}\text { BnF - Bibliothèque nationale } \\
\text { de France }\end{array}$ & 90.188 & $\begin{array}{l}\text { https://www.facebook.com/pages/ } \\
\text { BnF-Biblioth\%C3\%A8que-nationale-de- } \\
\text { France/298822067879 }\end{array}$ \\
\hline $\begin{array}{l}\text { BPI - Bibliothèque Publique } \\
\text { d'Information }\end{array}$ & 20.023 & https://www.facebook.com/bpi.pompidou \\
\hline Paris Bibliothèques & 6.654 & https://www.facebook.com/paris.bibliotheques/ \\
\hline
\end{tabular}

Source: http://bibliopedia.fr/wiki/Biblioth\%C3\%A8ques_sur_Facebook

Data de análise das páginas: 26.09.2016

Therefore, the research sample will be composed by three groups of selected public libraries (Brazil, Italy and France), in this sense, comprising 21 units of information mapped on Facebook. At first, it works with these groups through the application of specific software for analysis of social networks. Then, from the result of the analyses, we verify the strategies closest to the pre-established criteria for strategists on digital social media and with greater indication of elements that promote the digital presence.

\section{PROVOCATIONS: the new librarian's scenario}

Interactivity is the communication modality that acquires centrality on cyber culture. It expresses the conscious availability of a communicational context in a complex way, which is present in the message and provided by the sender, who opens the receiver possibilities to respond to the system in a dialogical way. This current perspective of communication represents a qualitative leap and modifications with regard to the mode of transmission of information to the mass that prevailed until the end of the XX century. The mode of interactive communication threatens the univocal logic of the media of mass, perhaps as an overcoming of the embarrassment of passive reception.

In this context, digital social media has potentially provided new experiences in relationships, participation, dialogues and bi-directionality through the forms of technologically mediated interaction. 
The study that is under development has been using authors who fit in the systemic perspective. The book General theory of systems, by Bertalanffy (1977), is a classic for this type of interpretation. For this author it is not possible to study parts and processes in an isolated way, and it is necessary to observe and solve the problems that arise in the processes that involve the parties at the moment of their dynamic interaction. In other words, it is necessary to be attentive to the movement of the organization and the order that unifies the parts.

Thus, because it is a study that contemplates this movement of interaction that happens in social media between the parties (librarian and integral user), the systemic perspective allows capturing the complexity of the interacting elements, in order to understand if there are elements that indicate the strategist librarian on digital social media. From this point of view, it is appropriate to use Edgar Morin's reflections (2000, 2006 and 2009) to deal with issues related to transdisciplinality and complexity.

In this systemic perspective, the contributions on postmodernity, hypermodernity, consumption and narcissistic individualism developed by Gilles Lipovetsky (1999, 2004a and 2004b) in his works, The Age of the Void and Hypermodern Times, are also relevant. As Bauman (2001, 2003 and 2008) dealt with issues related to community, liquid modernity and life for the consumption of information and products perpetuated by the desire and stimulation of dissatisfaction, embedded in the strategic mechanisms of the "consumer society", and also the slowness which, in the postmodern liquid world, indicates the social death and constant need of the subject of attention.

As interaction (librarian-user, machineman, one-all, all-all, and one-one) one of the aspects that has inevitably been addressed is the interactive dynamics between actors and contexts. Thus, the notes of Primo (2007, 2013) are interesting to explain such dynamics. The understanding of network interaction is relevant to formulate an acceptation that glimpses the possibilities of the strategist librarian on social media.

The acceptation of technology understood in this proposal is supported by the author A. V. Pinto (2005a; b). For purposes of this study, technology is understood as the set of all techniques influenced by the historical process of a society. It is also worth noting the propositions to think about the technologies of Dominique Wolton (2012), trying to reduce the pressure of the technique on communication. In the work titled Internet et après? This theorist of communication argues that the essential of the technique belongs to another order, that is, cultural and social, focusing on social relations.

Who discusses digital inclusion in the context of the public library (LAIPELT, MOURA, CAREGNATO, 2006; Freire, 2006; NEVES, 2017), especially in postgraduate course, has an understanding of the technologies of information and communication (TICs), indicating how it can be used or appropriated by a person in the mediation process of information. Thus, the concept of information behind the ideas advocated in this text is that discussed by Capurro and Hjorland (2007). It is agreed with the combination of semantics and pragmatics in the retrieval of information, proposed by the authors, that text, document, semantics and meaning are related to information. Information conception is also used in Information Science which comprises it as a structured set of coded mental representations, socially contextualized and capable of being registered in any material support and, consequently, communicated in an asynchronous and multidirectional way (SILVA; RIBEIRO, 2008).

The theoretical and conceptual foundation on digital marketing will be based on wellknown authors like: Oliveira (2003), Amaral (2008), Adolpho (2011), Rocha, Silva and Maia (2012), Barger (2013), Melgarejo Strutzel (2015). Thus, the following concept is elaborated: Digital marketing for information units is understood as an important strategy for the information units to enhance the attraction of integral users, the exponential dissemination of their information products and services, and as a resource capable of providing the librarian with the necessary strategies to develop digital presence in social media.

The texts about social and collaborative networks, organized by Población, Mugnaini and Ramos (2009) will also be useful in the discussions about networks, as well as associated to Johnson (2011) in the treatment of network analysis. Digital social media does not change its product, brand, feature or service (BARGER, 
2013). If librarians are no longer predisposed to dialogue, they are nor even likely to listen to what their partners and users (target audience or potential) have to say. Being on digital social media alone does not guarantee a significant number of likes, members or followers, whether on Facebook or Twitter.

\section{ASSUMPTIONS OF SOCIODIGITAL INCLUSION}

In order to observe the concept of sociodigital inclusion, which supports the stimulation of research on digital marketing in public libraries and the formulation of a concept that presents the strategist librarian on social media, the studies of Demo (2002, 2009 and 2013), Freire (2006), Dijk (2006 and 2008), Warschauer (2007) and Neves (2017) are all interesting.

The notion that permeates, or support, the theme may influence the defense of the debate that directs the subject in the context of digital marketing as a new perspective for the debate of sociodigital inclusion in public libraries. In more than ten years studying digital inclusion, it has been possible to realize that there is still a long way to go with regard to the discourses and practices of the actors involved.

The term resources convergence for digital inclusion in information units concerns the simultaneous application of digital (language and content), physical (computers and connectivity), human (literacy and education) and social resources (communities and institutions) (WARSCHAUER, 2003, 2006).

While the terms digital exclusion and digital literacy are coming into common use, for the discussions articulated by researchers and policy makers, digital inclusion is still a provocation. Digital inclusion is a broader category that addresses the others (MARYLAND, 2016).

It is important to emphasize that "sociodigital inclusion" has been articulated at the level of the political category, specifically to address issues of opportunity, access and skills. Considering that the discussion about the 'digital divide' tends to focus on the access available to individuals, sociodigital inclusion is used to signal a practical, policy-driven approach that addresses the needs of the communities as a whole. In a nutshell, sociodigital inclusion is a context of the social group, whose understanding is most favored when it is observed in the political category, and a milestone for evaluation and prospection, considering the disposition of the communities in its movement (DIJK, 2006; 2008) facing the various situations in the digital age.

The understanding of inclusion that supports the conception of sociodigital inclusion, which is backed on this study, is based on the concept of social integration (CASTEL, 1997 and 1998), in which individuals are included and excluded simultaneously in the world, in the system, etc., depending on the perspective of the object of desire. However, even these individuals on the sidelines pressure and influence the whole system.

This aspect also finds support in the discussion carried out by Demo (2002), when he observes the 'charm' attributed to the concept of social exclusion. This debate involving the dialectical pair "exclusion and inclusion", as well as the perspective of social integration, has been quite important for the field of social sciences. When it is necessary, the network society theory of Castells (1999 and 2000) is revisited to explain the network concept. Networks are open structures capable of unlimited expansion, integrating new 'nodes' as long as they can communicate within the network, that is to say, as long as they share the same communication codes.

Although the humbler people, slowly and slowly, are included in the digital world, this access is on the order of "trickle down". The logic of the market, on the one hand, reduces the productive process of digital artifacts, which may facilitate the marginalized lives (NEVES, 2017).

But the same logic relentlessly reserves the best chances for those who already have it. As critical educators say, the public education system itself, if it is not properly managed, is overwhelmingly bound to improve even better the chances of minorities (ARUM, ROKSA, 2011).

However, sociologists are not the main axis of this paper, but certainly they lubricate the cogs of the discussion of our analysis. After all, it is considered the premise that digital marketing can provide strategies capable of enhancing the interaction between librarians and users in digital social media as an access prerogative, 
insertion or emancipation of these individuals in a new paradigm implemented by innovation and technology. It is worth noting that the digital marketing perspective, addressed here, will not be focused on the market, but rather on the creation of effective strategies to provide the digital presence of subjects and non-profit institutions on social network.

\section{ESSENTIAL ASPECTS OF DIGITAL MARKETING: potentiality in public libraries}

Creating and managing the digital presence of the information units is becoming essential in the work of the professional librarian.

Data on social networks indicate that Brazilians spend 650 hours per month on digital social media. It is worth noting that $72 \%$ of all Internet users are active on social media.

- $\quad 89 \%$ of people between the ages of 18 and 29 are social network users,

- $\quad 72 \%$ of individuals aged from 30 to 49 years are social network users,

- $60 \%$ of people between the ages of 50 and 60 are users of social networks,

- $\quad 43 \%$ of people over 65 are engaged on social networks,

- $\quad 71 \%$ of users access social media from a mobile device (smartphones or tablets).

As it is possible noticing, they are high numbers in all circumstances. Given this context, the question is: why and how can the public library participate more actively in this movement?

Although it is common sense that the $Y, Z$, or Millenium generations are generally better off in the digital world than adults, it is understood that it is not that they have - for just have been born at this technological moment - such skills as if by magic. It is possible to observe that even in more developed (first world) countries, like the United States, there are still many children and teenagers whose contact with technology is rudimentary. (AU, 2009). In the same way as companies, non-profit organizations, like libraries, must also be present in this movement. Information units (libraries, centers and information and documentation systems), despite being non-profit social organizations, provide tangible and intangible services to society through operations that also require the definition and application of strategies. These units are influenced by the market, globalization and technologies, in the same way as companies that produce financial results (SPUDEIT; FÜHR, 2011).

The digital social media works as a perfect instrument for building good relationships between target and potential audiences, with or without the librarian's mediation. If the 'trace' left by the older connections is sustained by a successful relationship, the tendency is that the effect 'follow like sheep' gets spread. However, monitoring is one of the elements that drive the engagement of the bonds in established relationships.

In an attempt to guarantee this result, it has been agreed to adjust the concept of digital marketing to information units. The focus of Digital Marketing is to develop marketing strategies through the Internet. With this perspective, the organizations, consumers, institutions and their users, of diverse categories, seek total interactivity in their relationships, providing fast, personalized and dynamic information exchange. The "[...] Web Marketing, or Digital Marketing, corresponds to every concentration of efforts to adapt and develop marketing strategies in the Web environment" (OLIVEIRA, 2000, p.4).

It is necessary to deepen proposals of some marketing strategies using web 2.0. According to Rocha, Silva and Maia (2012), this proposal was based on Webber's marketing cycle in 2001. The digital marketing in libraries lacks the planning, strategy and support of additional interconnected channels.

More than a library having a website, page, group and-or profile on digital social media, being present in social networks, according to Strutzel (2015), refers to a set of factors, frequently external, and mainly to efforts by the institution, which help to build their representation and, consequently, their digital presence. Digital marketing indicates that, before initiating the first online actions, the entity (library) needs to develop its internal culture focused on digital media.

Here are four steps for digital marketing in libraries. This elaboration was made from an adaptation, based on Strutzel (2015): 
1. Existence of the unit of information: it is not enough just to be present, it is necessary to make presence! It's not just having a website, but being active on the Web.

2. Attracting member users: attracting the target audience; key people; contact points and content need to be relevant to the real and potential audience.

3. Relationship between links: maintaining a stable relationship with the audience. Attention to comments.

4. Engagement of librarians, users, and managers: maximum level of relationship between users and library products, resources and services. The spontaneous media happens through it.

The practical definition of Marketing corresponds to the activity of understanding the market to identify, conquer, and maintain customers, developing profitable relationships that will satisfy their needs. (STRUTZEL, 2015). From the digital marketing perspective, this principle expands to the interactions enhanced by digital social media.

The technological growth, currently experienced, determines significant changes on the social context. In contemporaneity, it is possible to observe the changes provoked on the social web, like permissions to answer surveys, to criticize things on websites, blogs and microblogs; to participate on social networks on the Internet, and others things like that. The content is exposed on open and interactive platforms (BLATTMANN; SILVA, 2007).

Naturally, the focus in this article lies in the potential and fundamental issues of the social web (web 2.0) for the information units, specifically in the context of public libraries. In this way, social networking technology has been seen as a key element of contemporary organizational and relational approaches (JOHNSON, 2011). Its analysts appreciate to observe how data, information and knowledge circulate in their horizontal and vertical flows, providing links as relationships.

This second form of the web, called social web, has raised the concept of social network to other levels, driven by digital social media. Digital social media is an environment in which "[...] the barriers to data publishing disappear, transforming anyone with a good Internet connection into a potential publisher, and consequently into a reliable source of Information "(BARGER, 2013, p.2).

It is worth emphasizing that the concept of 'social' will always be more relevant than that of 'media'. Platforms - such as Facebook, YouTube, Snapchat, Instagram, Pinterest, Linkedin and Twitter, as well as wikis, microblogs, podcasts, and others - boost the dynamics between links, though they cannot provoke themselves by their own (BARGER, 2013). This is a point that interests and supports the argument of this discussion, because the strengthening of the dynamics of the relations can happen when the strategies of the leader of the information unit are implemented in a conscious, active, coherent and purposeful way. Dual-handed dynamics are the most important aspect of digital social media. It needs to be clear in the organizers' mind if it is intended to promote any product or service.

According to Gunelius (2012), having a website on the World Wide Web is no longer a low-priority investment. That is, in the contemporary context, it is a necessity, aiming to guarantee the survival of the institution. For an information unit, building relationships with its users in the online environment needs to be seen as something more important than borrowing books in the library's physical environment, for example. This is a trend that already happens in other segments, especially dictated by the consumers of products and services. It is easy to observe that in cases like "Magazine Luiza", and others.

In this context, the librarian strategist on digital social media needs to have this principle clearly in his goal and action plans that aim to present, in these environments, products, resources and services of information units.

Based on Barger (2013), it can be inferred that the digital social media of a library should not be created without a well-defined purpose. According to this author, companies and organizations adhere to social media because they want to: 1) attract more customers, especially potential ones, to consume their products or services; 2) make their customers feel better after purchasing their products; 3 ) in case of any problem, after the purchase of their goods, they want to have fast solutions; 4) Understand what would make their customers more predisposed 
to consume more of their products in the future. Generally, these reasons are expected to be clear to companies, and 'dialogue' and 'engagement' has to be established to achieve these ends.

\section{FINAL CONSIDERATIONS}

This article sought to present the main advances found in the context of an ongoing research whose general objective is to investigate aspects of the strategist librarian on digital social media as a contemporary element of sociodigial inclusion.

It brought as main elements the method and the universe of research, trying to demonstrate the relevance of the continuity of this study, which presents as the main contribution, for the public library institutions, the exploration of the concept of digital marketing in the context of information units. In this sense, it is known that this is a pioneering study that has been concerned with adjusting, with the care of scientific rigor, the concepts coming from marketing on social media.

Another point worth mentioning is the intention to elaborate the meaning 'strategist librarian on social media'. It has been an effort to deepen this theme and, at the same time, a satisfaction to have contact with the essential concepts of digital marketing to develop this concept, still unprecedented in Information Science. It is understood that this deepening is essential for all information professionals who want to continue the interaction with their users and keep libraries a living environment, either in the online or physical context, considering the evolutions in the contemporaneity and the future.

Thus, this text brought the main aspects which are essential to address digital marketing in public libraries and the proposition of the concept that addresses the potential of strategist librarians on digital social media. It is hoped that they may join other studies on social networks in libraries, in the field of Librarianship and Information Science, pointing out a proposition of concept for discussion. It is also envisaged that strategist librarians may serve as an inspiration for broadening the debate on the theme that articulates digital marketing as a subsidy for the development of public information policies for sociodigital inclusion in public libraries.

\section{Artigo recebido em I5/04/20 I8 e aceito para publicação em II/05/20 I8}

\section{BIBLIOTECA ESTRATEGISTA NA MÍDIA SOCIAL: Abordagem conceitual e possibilidades de marketing digital em bibliotecas públicas}

RESUMO

O artigo tem como tema o bibliotecário estrategista em mídias sociais, considerando aspectos do marketing digital para inclusão sociodigital em bibliotecas públicas. Apresenta alguns elementos de uma pesquisa em andamento que tem como pergunta de partida saber como a biblioteca pública vem desenvolvendo estratégias para inclusão sociodigial, por meio da introdução de mídias sociais, considerando aspectos do marketing digital. $O$ objetivo geral visa investigar aspectos e possibilidades do bibliotecário estrategista em mídia social digital, como elemento contemporâneo da inclusão sociodigial. A pesquisa é de caráter exploratório e descritivo, com abordagem qualitativa e quantitativa, com a metodologia de estudo de casos múltiplos com aplicação de método de avaliação de redes sociais digitais e bibliográfico. Os resultados apresentam a primeira etapa do estudo completo, que se encontra em andamento. Desse modo, destaca os aspectos essenciais para se abordar o marketing digital em bibliotecas públicas e a proposição do conceito que aborda o potencial do bibliotecário estrategista em mídias sociais digitais. Considera relevante, ao final, apontar no campo da Biblioteconomia e da Ciência da Informação, como o novo conceito de discussão, o bibliotecário estrategista, servindo de inspiração para ampliação do debate sobre a temática que articula marketing digital como subsídio para o desenvolvimento de políticas públicas de informação para inclusão sociodigital em bibliotecas públicas.

Palavras-chave: Bibliotecário estrategista - elaboração de conceito. Marketing digital. Mídia social digital. Comunicação e Tratamento da informação. Inclusão sociodigital. 


\section{REFERÊNCIAS}

AMARAL, S. A. do. Os 4Ps do composto de marketing na literatura de ciência da informação. Brasília, v. 12, n. 2, p. 51-60, jul./dez. 2000.

Marketing da informação: entre a promoção e a comunicação integrada de marketing. João Pessoa, v. 18, n. 1, p. 31-44, jan./ abr. 2008.

AMERICAN ASSOCIATION OF SCHOOL LIBRARIANS (AASL). Information Power: Building Partnerships for Learning. 1998.

$\begin{array}{lrr}\text { AMERICAN } & \text { ASSOCIATION of } & \text { SCHOOL } \\ \text { LIBRARIANS; } & \text { ASSOCIATION } & \text { for } \\ \text { EDUCATIONAL } & \text { COMMUNICATIONS }\end{array}$

AND TECHNOLOGY. Information Literacy Standards for Student Learning. Chicago: American Library Association, 1998. Disponível em: < http://www.ilipg.org/sites/ilipg.org/ files/bo/InformationLiteracyStandards_final. pdf $>$.

ASSUMPÇÃO, R.; MORI, C. Inclusão digital: discursos, práticas e um longo caminho. In: e-Desenvolvimento no Brasil e no mundo: subsídios e programas e-Brasil. São Paulo: Yendis, 2007.

ARUM, R ; ROKSA, J. Academically Adrift :limited learning on college campuse. Chicago: The University of Chicago Press, 2011.

AU, W. Unequal by Design: High-stakes testing and the standardization of inequalit. London: Routledge, 2009.

AUSTRALIAN AND NEW ZEALAND INSTITUTE FOR INFORMATION LITERACY (ANZII). Australian and New Zealand information literacy framework. 2. ed. 2004. Disponível em: < http:/ / www.library.unisa.edu. $\mathrm{au} /$ learn/infolit/infolit-2nd-edition.pdf $>$. Acesso em: 18 abr. 2014.

BARGER, C. O estrategista em mídias sociais. São Paulo: DVS, 2013.
BELLARDO, T.; WALDHART, T. J. Marketing products and services. Libri, v. 27, n. 3, p. 181194, Mar., 1977.

BERNADINO, M. C. R.; SUAIDEN, E. O papel social da biblioteca pública na interação entre informação e conhecimento no contexto da ciência da informação. Perspectivas em Ciência da Informação, v.16, n.4, p.29-41, out./dez. 2011.

BERTALANFFY, L. V. Teoria geral dos sistemas. Tradução de Francisco M. Guimarães. Petrópolis: Vozes, 1977.

BAUMAN, Z. Modernidade Líquida. Tradução Plínio Dentzien. Rio de Janeiro: Jorge Zahar, 2001.

. Comunidade. Tradução Plínio Dentzien. Rio de Janeiro: Jorge Zahar, 2003.

Vida para o consumo: a transformação das pessoas em mercadorias. Rio de Janeiro: Jorge Zahar, 2008.

BEUREN, I. M. et al. Como elaborar trabalhos monográficos. $1^{a}$ ed. São Paulo: Atlas, 2003.

BIBLIOTECA PÚBLICA: princípios e diretrizes. 2. ed. Rio de Janeiro: Fundação Biblioteca Nacional, 2010.

BLATTMANN, U; SILVA, F.C.C. Colaboração interação na web 2.0 e biblioteca 2.0. Revista Acb: Biblioteconomia em Santa Catarina, Florinópolis, v. 12, n. 2, p.191-215, jul. 2007. Disponível em: <http://revista.acbsc.org.br/racb/article/ view/530>. Acesso em: 16 jun. 2014.

BOGDAN, R.; BIKLEN, S. - Características da investigação qualitativa. In: Investigação qualitativa em educação: uma introdução à teoria e aos métodos. Porto, Porto Editora, 1994. p. 4

BRASIL. Sociedade da informação: ciência e tecnologia para a construção da sociedade da informação no Brasil. Brasília, 2000. 
BUNDY, A. Australian and New Zealand Information Literacy Framework: principles, standards and practice. 2. ed. Adelaide: Australian and New Zealand Institute for Information Literacy, 2004. Disponível em: < http://www.library.unisa.edu.au/learn/infolit/ infolit-2nd-edition.pdf>. Acesso em: 02. Jul. 2014.

BUZATO, Marcelo. Entre a fronteira e a periferia: linguagem e letramento na inclusão digital. 2007. Tese (Doutorado) - UNICAMP, 2007.

CAPURRO, R.; HJORLAND, B. O conceito de informação. Perspectiva em Ciência da Informação, v.12, n.1, 2007.

CASTEL, R. As armadilhas da exclusão. In: Wanderley, M. B.; Bógus, L.; Yasbek, M. C. (Org.). Desigualdade e Questão Social. São Paulo: EDUC, 1997. p. 15-48.

As metamorfoses da questão social: uma crônica do salário. Trad. Iraci Poleti. Petrópolis: Vozes, 1998.

CASTELLS, M. La era de la información: economía, sociedad y cultura - el poder de la identidad. 5.ed. Madrid: Alianza, 2001a. v. 2.

La era de la información: la sociedad en red. Madrid: Alianza, 2001b. v. 1.

CERVERÓ, Aurora Cuervas; GONZÁLEZ, Inmaculada Vellosillo. Bibliotecas na pratica da inclusão digital. In: CUERVAS, Aurora Cuervas; SIMEÃO, Elmira (Org.). Alfabetização informacional e inclusão digital: modelo de infoinclusão social. Brasília: Thesaurus, 2011. Cap. 3. p. 11-219.

COMITÊ GESTOR DA INTERNET NO BRASIL. Pesquisa sobre o uso das tecnologias de informação e da comunicação no Brasil: 2010. São Paulo: CGI.br, 2010. Disponível em: <www. cgi.br>. Acesso em: set. 2011.

DEMO, P. Educação hoje: "Novas" tecnologias, pressões e oportunidades. São Paulo: Atlas, 2009.
Charme da exclusão social. Campinas: Autores Associados, 2002.

Metodologia da investigação em educação. Curitiba: InterSabere, 2013.

DIJK, J.A.G.M Van. The Deepening divide: inequality in the information society. Thousand Oaks: Sage Publicaions, 2005. 240 p.

The Network society: social aspects of new media. 2 ed. London: Sage Publication, 2006. 292p.

Internet skills and support matter, The Relationship Between Skills, Sources of Support and Beneficial Internet, 2012. p. 24-28. Disponível em:<http://alexandervandeursen. nl/serendipity5/uploads/pubs/ICa2012 IntenetSkillsansSupportMatter.pdf $>$. Acesso em: 04 jun. 2014.

FEITOSA, A. Organização da informação na web: das tags à web semântica. Brasília: Thesaurus, 2006.

FREIRE, I. M. Acesso à informação e identidade cultural: entre o global e o local. Ci. Inf., Ago 2006, vol.35, no.2, p.58-67.

GUNELIUS, S. Marketing nas mídias sociais em 30 minutos. São Paulo: Cultrix: 2012.

HERNÁNDEZ SAMPIERI, R.; FERNÁNDEZ COLLADO, C.; BAPTISTA LUCIO, M. del. 5. ed. Metodologia de pesquisa. Porto Alegre: Penso, 2013.

HETKOWSKI, T.M. (org.). Políticas públicas e inclusão digital. Salvador: Edufba, 2008.

HIMANEN, P.. La ética del hacker y el espíritu de la era de la información. Barcelona: Destino, 2003.

INSTITUTO ANTONIO HOUAISS. Grande Dicionário Houaiss da Língua Portuguesa. Disponível em: <http://houaiss.uol.com.br>. Acesso em: 01 jul. 2015. 
JANESICK, V. J. Stretching exercises for qualitative researchers. Thousand Oaks: SAGE, 1998.

LAIPELT, R. do C. F.; MOURA, A. M. M.; CAREGNATO, S. E. Inclusão digital: laços entre bibliotecas e telecentros. Informação e Sociedade, João Pessoa, v. 16, n. 1, 2006, p.285295. Disponível em: <http://bogliolo.eci.ufmg. br/downloads/ LAIPELT\%20Inclusao $\% 20$ Digital.pdf>. Acesso em: 25 mar. 2012.

LASTRES, H. M. M.; ALBAGLI, S. Informação e Globalização na Era do Conhecimento. São Paulo: Campus, 1999.

LAU JESÚS. Guidelines on information literacy for lifelong learning. IFLA. 2006. Disponível em: < http://www.ifla.org/files/assets/informationliteracy/publications/ifla-guidelines-en.pdf>. Acesso em: 17 abr. 2014.

LEMOS, A. Cibercultura: tecnologia e vida social na cultura contemporânea. Porto Alegre: Sulinas, $4^{\mathrm{a}}$ ed, 2008.

LEMOS, A.; LÉVY, P. O futuro da internet: em direção a uma ciberdemocracia planetária. São Paulo: Paulus, 2010.

LÉVY, P. A inteligência coletiva: por uma antropologia do cirberespaço. Trad. Luiz Paulo Ruanet. 5ed. São Paulo: Loyola, 2007.

Cibercultura (trad. Carlos Irineu da Costa). São Paulo: Editora 34, 1999.

LIPOVETSKY, G. A era do vazio: ensaio sobre o individualismo contemporâneo. Tradução Miguel Serras Pereira; Ana Luísa Faria. Lisboa: Relógio d'água, 1989.

O império do efêmero: a moda e seu destino nas sociedades modernas. Tradução Maria Lucia Machado. 7.ed. São Paulo: Companhia das Letras, 2004a.

Os tempos hipermodernos. Tradução Mário Vilela. São Paulo: Barcarolla, 2004b.
KOTLER, P. Administração de Marketing. São Paulo: Prentice Hall, 2000

MARCONI, M. A.; LAKATOS, E. M. Metodologia do trabalho cientifico. 8. ed. São Paulo: Atlas, 2013.

MARYLAND. Institute Of Museum And Library Services. American Library Association (ALA) (Org.). What is Digital Inclusion: Digital inclusion has three broad facets. 2016. University of Maryland. Disponível em: <http:/ / digitalinclusion.umd.edu/content/what-digitalinclusion>. Acesso em: 13 ago. 2016.

MELGAREJO, C. R. Marketing digital em bibliotecas. Disponível em: $<$ http:// www.bibliotecadigital.unicamp.br/ document $/ \% 3 F d o w n \% 3 D 23466 \& r c t=j \& f r m=$ $1 \& \mathrm{q}=\&$ esrc $=\mathrm{s} \& \mathrm{sa}=\mathrm{U} \& \mathrm{ei}=\mathrm{O} 9 \mathrm{OBVen} \times \mathrm{H} 4 \mathrm{TEgwS5}$ zIKYBw\&ved= OCBYQFjAA\&usg= A F Q j C N H T y 3 D L g N 398 b Y U 7 ChUq1rNvOQHVw>. Acesso em: 30 maio 2016.

MORIN, E. Introdução ao pensamento complexo. Porto Alegre: Sulina; 2006.

Os sete saberes necessários à educação do futuro. São Paulo: Cortez; 2000.

A cabeça bem feita: repensar a reforma reformar o pensamento. Rio de Janeiro: Bertrand Brasil, 2009.

MOROZOV, E. The net delusion: the dark side of internet freedom. New York: PublicAffairs, 2011.

Formação e orientação: aspectos da mediação no universo da inclusão digital. Revista Inclusão Social, v. 5, p. 44-57, 2012. Disponível em: $\quad<$ http://revista.ibict.br/inclusao/index. $\mathrm{php} /$ inclusao/article/view/177>. Acesso em: 04 jun. 2013.

NEVES, B. C. La inclusió digital i el context brasiler: una experiècia em els dominis d'una universitat. Revista BID, Barcelona, v.21, tradución: LuisAugust, 2008. 
NEVES, B. C.; COUTO, E. S. COUTO, M. Fundamentos e agenda da inclusão digital no Brasil: pesquisas em educação. Educação (PUCRS. Impresso), 2016.

Perspectivas de treinamento e orientação: contextos da mediação no universo da inclusão digital. Revista Iberoamericana de Ciencia Tecnología y Sociedad (En Línea), v. 9, p. 1-21, 2014.

OLIVEIRA, J. F. de. T.I.C: Tecnologias da Informação e da Comunicação. São Paulo: Érica, 2003. p. 444.

PINTO, Á. V. O conceito de tecnologia. Rio de Janeiro: Contraponto, v.1, 2005a.

O conceito de tecnologia. Rio de Janeiro: Contraponto, v.2, 2005b.

PRIMO, A. Interações em rede. Sulinas: Porto Alegre, 2013.

Interação mediada por computador: comunicação, cibercultura, cognição. Sulinas: Porto Alegre, 2013.

RECUERO, R. Redes sociais na internet. Porto Alegre: Sulina, 2009.

SCHOOL LIBRARIES WORK!. S.l: Scholastic, 2006. 20p.

SANTAELLA, L. Navegar no ciberespaço: o perfil cognitivo do leitor imersivo. Ed.2. São Paulo: Paulos, 2007.

SILVA, A. M.; RIBEIRO, F. Das ciências documentais à ciência da informação: ensaio epistemológico para um novo modelo curricular. Porto: Afrontamento, 2008.

SORJ, B; MARTUCCELLI, D. O desafio latinoamericano: coesão social e democracia. Rio de Janeiro: Civilização Brasileira, 2008.

SORJ, Bernardo. A democracia inesperada. Rio de Janeiro: Jorge. Zahar, 2004.
A nova sociedade brasileira. 3 ed. Rio de Janeiro: Jorge Zahar, 2006.

Brasil@povo.com: a luta contra a desigualdade na sociedade da informação. Brasília, DF: UNESCO, 2003.

ROCHA, E. S.; SILVA, M. R; MAIA, M. B. Estratégia de marketing em unidades de informação: o uso de ferramentas da web 2.0. Revista ACB: Biblioteconomia em Santa Catarina, Florianópolis (Brasil), 2012.

SPUDEIT, D. F. A. O.; FUHR, F. Planejamento em unidades de informação: qualidade em operações de serviços na Biblioteca do SENAC Florianópolis. Bibl. Univ., Belo Horizonte, v.1, n.1, p. 41-49, jan./jun. 2011. Disponível em: https://www.bu.ufmg.br/rbu/index.php / localhost/article/view/16/18>. Acesso em 13 mar. 2013.

STRUTZEL, T. Presença digital. Rio de Janeiro: Alta Books, 2015.

SUAIDEN, E. Biblioteca pública e informação à comunidade. São Paulo: Global, 1995.

POBLACIÓN, D. A; MUGNAINI, R.; RAMOS, L. M. S. V. Redes sociais e colaborativas: em informação científica. São Paulo: Angellara Ed., 2009.

TOMAÉL, M. I. Redes sociais, conhecimento e inovação localizada. Informação \& Informação, Londrina, v. 12, n. esp., 2007.

TOMAÉL, M. I.; ALCARÁ, A. R.; CHIARA, I. G. Di. 2005. Das redes sociais à inovação. Ciência da Informação, Mai.-Ago. 2005, vol. 34, no. 2; p.93104.

UNESCO. MANIFESTO DA IFLA/UNESCO sobre bibliotecas públicas, 1994. Disponível em: <http:/ / archive.ifla.org/VII/s8/unesco/port. htm>. Acesso em: 15 fev. 2011. 
WARSCHAUER, M. Going one-to-one. Association for Supervision and Curriculum Development, Educational Leaderschip, London, v.62, n.1, 2005.

Laptops and literacy: learning in the wireless classroom. New York: Teaches College Press, 2007.
Learning the digital age. Educational Leaderschip, London, v.63, n.4, dec.2005-jan 2006b, p. 34-38.

Technology and social inclusion: rethinking the digital divide: MIT, 2003. Disponível em: <http://www.mitpress.mit. edu/catalog/item/ default.asp?sid=BAC81CFA2B4A-44FF.html>. 